\title{
Exploring and Conceptualizing Workplace Spirituality in Islamic Banks
}

\begin{abstract}
Mehboob ur Rashid ${ }^{1}$, Humera Manzoor ${ }^{2}$, Usman Ghani ${ }^{3}$
Abstract

This study investigates workplace spirituality in Islamic banks in Pakistan. Through qualitative approach, this study seeks to understand the meaning employees give to workplace spirituality in Islamic banks and explores the way workplace spirituality is constituted and enacted at workplace. It takes an epistemological stance of social constructionism and argues that the way people define workplace spirituality is subjective in nature. Data has been collected from 22 respondents working in Islamic banks and has been analyzed through thematic analysis. Findings reveal that all respondents defined workplace spirituality in terms of religion. They found inner peace and happiness by serving humanity and religion and had deeper concerns for earning 'halal' or 'haram'. Also, the confusion created due to conflicting fatwas on Islamic banks influenced job satisfaction which is seen as a component of workplace spirituality in literature. This study theoretically contributes that workplace spirituality is highly contextual in nature and religiosity and spirituality cannot be treated as separate in organizations that are based upon religious foundations.
\end{abstract}

Keywords: Workplace spirituality, religiosity, social constructionism, Islamic banks

\section{Introduction}

The significance of workplace spirituality in modern organizations cannot be undermined despite of all hesitances to study the concept particularly in the Western context that was traditionally tied to religion (Freshman, 1999). Research shows that workplace spirituality improves employee well-being (Garg, 2017), employee work attitudes (Milliman, Czaplewski, \& Ferguson, 2003), behavior and job satisfaction (Van der Walt \& de Klerk, 2014), organizational commitment (Rego \& Pina e Cunha, 2008), reduce work stress (Daniel, 2015), create ethical organizations and increase organizational performance (Garcia-Zamor, 2003), and so forth. Though a substantial research exists that determines the influence and relationships of workplace spiritu-

1 Assistant Professor, Institute of Management Studies, University of Peshawar Email: mehboob@uop.edu.pk 2 Assistant Professor, Institute of Business Studies, Kohat University of Science and Technology, Pakistan.

3 Associate Professor, Institute of Management Sciences, Peshawar. email:usman.ghani@imsciences.edu.pk

\begin{tabular}{ll} 
ARTICLE HISTORY & \\
8 Mar, 2019 Submission Received & 28 Mar, 2019 First Review \\
\hline 2 Apr, 2019 Second Review & 7 May, 2019 Third Review \\
\hline 20 May, 2019 Accepted &
\end{tabular}


ality on various organizational factors; an in-depth literature review indicates that the research is still in its infancy and even the canvas of the special interest group of management, spirituality and religion of the Academy of Management is still blank (Tackney et al., 2017). This is mainly due to the dichotomy between religion and spirituality and the subjective and elusive nature of the phenomenon that could mean different things to different people (Houghton, Neck, \& Krishnakumar, 2016).

Current research on workplace spirituality is being criticized for the lack of theoretical foundations and academic rigor mainly due to absence of mutually agreed definition of workplace spirituality (Houghton et al., 2016; Milliman et al., 2003). Hence, there is a lack of conceptual clarity in defining workplace spirituality due to its highly personal and subjective nature (Benefiel, 2003; Tackney et al., 2017). Researchers get confused and entangled in various perspectives that define workplace spirituality that may or may not include religion (Hill et al., 2000; Neck \& Milliman, 1994; Osman-Gani, Hashim, \& Ismail, 2013; Tackney et al., 2017). Thus, this study aims to address the lack of conceptual clarity in defining workplace spirituality and unfolds the connection between religion and workplace spirituality. It argues that religiosity is an integral aspect of workplace spirituality in contrast to several western researchers who think that spirituality is a genuine topic for discussion at workplace, but religion is a divisive factor at workplace and should be avoided (e.g. Gotsis \& Kortezi, 2008; Krishnakumar \& Neck, 2002; Zinnbauer, Pargament, \& Scott, 1999; Mitroff \& Denton, 1999; Tackney et al., 2017). Hence, to overcome this conceptual gap, this study aims to explore workplace spirituality among the employees of Islamic banks in Pakistan through a religious perspective. This is significant as the notion of religiosity in Islamic societies appears to boost the spiritual level of employees working in Islamic banks that is constructed on Islamic principles.

The way workplace spirituality is defined depends upon the theoretical stance of a researcher that highlights the complexity and diversity of the concept (Freshman, 1999). Fundamentally, it ranges from a positivist to a social constructionist view that guides the conceptual and methodological approach to study workplace spirituality. Benefiel (2003) has identified four ways to study workplace spirituality, which he calls the "trails" to study workplace spirituality - the quantitative trail, the deep "how" and "why" trail, and the radical "how" and "why" trail that employs qualitative methods. Despite of all its contributions, quantitative methods remained dominant but provide a limited view due to the difficulty in defining workplace spirituality (Pool, 2009). This study is positioned at the deep "how" and "why" trails to explore how and why workplace spirituality is enacted at workplace that has remained an under researched area and requires a qualitative approach (Benefiel, 2003; Pool, 2009). It takes a stance of social constructionism, which defines workplace spirituality as a social construct. 
This means that the way individuals define the concept is subject to their interpretation that could vary from one person to another (Burr, 2003). This further infers that the concept is highly contextual, and the meaning may vary in various contexts that is seldom found in the literature. Thus, this study aims to address the following research questions: what meaning do employees give to workplace spirituality? How workplace spirituality is constituted and enacted at workplace? Why employees in Islamic banks experience workplace spirituality?

This paper is constructed as follows: it begins with the literature review followed by a conceptual framework. The methodology is discussed afterwards followed by findings. Finally, the paper closes with the discussion and conclusion of the findings that highlights both its theoretical contributions and practical implications.

\section{Literature Review}

The term "spirituality" stems from the Latin root "spiritus", which means breath or life, and describes a person "of the spirit" (Hill et al., 2000). Historically, spirituality has been mainly referred to in terms of religion only but has now become one of the views of spirituality (Krishnakumar \& Neck, 2002). Proponents of the non-religious view of spirituality argue that being religious is a broad term that may not accommodate the "spiritual" component (King, 2007). This has been mainly due to advent of secularism in the Western societies that has excluded religion from workplace.

The study of spirituality has been categorized into different perspectives which vary among authors. For example, Twigg et al. (2001) have described spirituality in three ways: religious, metaphysical, and humanistic (also known as secular). Religious spirituality is about connection with God. Metaphysical is about a belief in a force greater than oneself (Witmer, 1989). The humanistic perspective focuses on the search for meaning of experiences beyond religion (Paloutzian, 1997). According to Spilka (1993, cited in Hill et al., 2001), the study of contemporary spirituality can be divided into three categories: a God-oriented spirituality where thought and practice are related to a certain theology, a world-oriented view that describes an individual's relationship with ecology or nature, and a humanistic view that stresses human achievement or potential. Krishnakumar \& Neck (2002) offers a similar description of spirituality: intrinsic-origin, religious, and existentialist views. The three views are presented in Table 1.

These perspectives are very useful in understanding spirituality, but they usually overlap (Kinjerski \& Skrypnek, 2004). Hence, a researcher should not aim to determine a definitive view rather the aim should be to understand the meaning of these views (Krishnakumar \& Neck, 2002). It should be noted that these different 
Table 1: Different Perspectives of Workplace Spirituality

\begin{tabular}{|c|c|c|}
\hline Spilka (1993) & Twig et al., 2001 & $\begin{array}{c}\text { Krishnakumar and Neck } \\
\text { (2002) }\end{array}$ \\
\hline $\begin{array}{c}\text { World oriented view: stress } \\
\text { one's relationship with ecology } \\
\text { or nature }\end{array}$ & $\begin{array}{c}\text { Metaphysical: a belief in a force } \\
\text { greater than oneself }\end{array}$ & $\begin{array}{c}\text { Intrinsic-origin view: originates } \\
\text { from inside the individual and } \\
\text { is related to inner conscious- } \\
\text { ness. }\end{array}$ \\
\hline $\begin{array}{c}\text { God-Oriented: thought and } \\
\text { practice are premised in the- } \\
\text { ologies, } \\
\text { either broadly or narrowly } \\
\text { conceived }\end{array}$ & Religion: connection with God & $\begin{array}{c}\text { Religious view: are related to } \\
\text { specific religion that "con- } \\
\text { sists of beliefs, actions, and } \\
\text { institutions which assume the } \\
\text { existence of supernatural enti- } \\
\text { ties with powers of action, or } \\
\text { impersonal powers or processes } \\
\text { possesses of moral purpose }\end{array}$ \\
\hline $\begin{array}{c}\text { A humanistic (or people-orient- } \\
\text { ed) spirituality: stress human } \\
\text { achievement or potential. }\end{array}$ & $\begin{array}{c}\text { Humanistic: search of meaning } \\
\text { of experiences beyond religion }\end{array}$ & $\begin{array}{c}\text { Existentialist view: search of } \\
\text { meaning of what one is doing } \\
\text { at workplace }\end{array}$ \\
\hline
\end{tabular}

theoretical perspectives indicate that religion is only one of the views of spirituality. In literature, there is a difference of opinion about whether religiosity or spirituality are related or are two distinct concepts. At times, both the terms are related by some of the researchers whereas others have treated them as two distinct concepts with different connotations. Hence, two schools of thought exist. Some researchers believe that religion and spirituality are related and that "there is no spirituality without religious thoughts and practices" (Rassool, 2000, p. 1479). The second view considers them as distinct and separate. For instance, Gani et al. (2013) have used different measures for spirituality and religiosity to measure their linkages on employee performance and have found that religion acts as a moderating variable to improve employee performance. Similarly, Koenig et al. (2001) differentiate spirituality and religiosity as follows:

Religion is an organized system of beliefs, practices, rituals and symbols designed (a) to facilitate closeness to the sacred or transcendent (God, higher power, or ultimate truth/ reality), and (b) to foster an understanding of one's relation and responsibility to others in living together in a community. Spirituality is the personal quest for understanding answers to ultimate questions about life, about meaning, and about relationship to the sacred or transcendent, which may (or may not) lead to or arise from the development of religious rituals and the formation of community (p.18).

Research shows that the rise of secularism in the West has demarcated spirituality 
and religiosity though both the terms have been used interchangeably in the earlier literature (Zinnbauer et al., 1999) but has now become distinct (Ashmos \& Duchon, 2000). In secular societies, the relationship between spirituality and religion has become problematic and spirituality can exist beyond religion. It is based on the assumption that spirituality based on religion is ill defined and cannot contribute to the scientific knowledge (Giacalone \& Jurkiewicz 2003). Hence, the role of religion has become limited to an isolated strand of the religious view of spirituality. This led researchers to propose alternative views of spirituality that describes spirituality beyond religion, which MacLaren (2004) terms it as "secular spirituality".

On the contrary, this paper argues that religiosity and spirituality could be used interchangeably when religious perspective of spirituality is taken. We will use the term "religious spirituality" as against the term "secular spirituality" as we have conceptualized workplace spirituality in terms of religiosity. Here, religiosity is not confined to attending masjids or performing religious rituals rather it is the connection of human being with God. Also, the notion of spirituality in religious term is provided in the ethics literature that argues that Islam provides a complete code of work ethics under the "Islamic Work Ethic", which is different from several other religions. The fundamental aspect of this code of ethic is to show generosity and to be fair and to do justice with one's own self and with the others (Yousef, 2000).

The notion of "halal" (i.e. what is permissible in Islam) and "haram" (i.e. what is not permissible in Islam) in the Islamic code of ethics guides a Muslim's attitudes and behavior (Wilson \& Liu, 2010). However, the magnitude of religious influence and how it shapes his behavior and attitude would vary from one person to another. People who have a strong affiliation towards their religion will follow its guidelines more as compared to others, which Mukhtar and Butt (2012) call religiosity - the degree to which one is religious. Though it has been found that the "halal" brands of consumable products have a profound impact on consumer's attitude, more work needs to be done to explore different product categories (Mukhtar \& Mohsin Butt, 2012). In the same vein, an interesting aspect would be to explore the spirituality that individuals derive at workplace when working in delivering halal products, such as, Islamic banks. This also relates to ethics though finance and ethics are considered to be separate. The financial crisis in the last decades has prompted people to question the ethics of banking sector due to unequal distribution of wealth and being unjust and unfair. Islamic banks offer a workplace for people to satisfy their religious and ethical beliefs since the main aim is to deliver Islamic products based upon moral and ethical principles. Further, research shows that the magnitude of religious aspect would vary from one person to another and so does his/her religious affiliation (Mukhtar \& Mohsin Butt, 2012). This makes Islamic banks an interesting case to explore in 
terms of workplace spirituality.

\subsection{Context of the study}

The context of this study is the Islamic banks that are fundamentally created on the basis of Shariah - Islamic law. The banks are interest free as riba "(premium that must be paid by the borrower to the lender along with the principal amount as a condition for the loan or for an extension in its maturity)" (Chapra, 1986, p. 262) and usury (the practice of lending money to people at unfairly high rate of interest) (Hornby, 2000, p. 1433) is forbidden in Islam because it results in accumulation of wealth in few hands; hence Islam has strictly prohibited interest-based transactions in its economic dealings. The Quran and the sunnah plays an important role in constituting Islamic laws, which defines what is halal and haram in Islam (Mukhtar \& Mohsin Butt, 2012). Thus, as narrated in Surah Al Baqarah, verse 275-281: "Those who benefit from interest shall be raised like those who have been driven to madness by the touch of the Devil; this is because they say: "Trade is like interest" while God has permitted trade and forbidden interest. Hence those who have received the admonition from their Lord and desist, may keep their previous gains, their case being entrusted to God; but those who revert shall be the inhabitants of the fire and abide therein forever.". Similarly, in the Hadith reported by Jabir: The Prophet Muhammad (P.B.U.H), cursed the receiver and the payer of interest, the one who records it and the two witnesses to the transaction and said: "They are all alike [in guilt]." (Muslim, Kitab al-Musaqat, Bab la'ni akili al-riba wa mu'kilihi; also, in Tirmidhi and Musnad Ahmad). This shows the extent to which interest is considered as an evil in an Islamic society as it prevents collective welfare and equal distribution of wealth. This explicitly reflects that the religious and ethical issues underpin the Islamic banking system.

The Islamic banks are based on the fundamental principle to avoid interest in all kinds of transactions, which is the main distinguishing feature from the conventional banks. It is based on profit and loss sharing basis in contrast to the conventional banks. However, the extent to which they are strictly based on the Islamic principles and values varies but the underlying foundation of Islamic banking remains Shariah compliance.

\section{Methodology}

This study takes a social constructionist approach and defines workplace spirituality as a social construct owing to the highly subjective nature of the phenomenon. The understanding and knowledge about a particular phenomenon is constructed by individuals themselves through their daily interactions; hence, qualitative research methods are used to explore this concept. Qualitative approach is well suited to the 
problems that need to be explored in depth (Creswell, 2005).

Data has been collected from 22 bankers working in Islamic banks that include top management team, middle managers, frontline staff members, and a mufti who was an auditor as well through purposive and convenience sampling (Patton, 1990). The interviews were semi-structured and ranged from 20 to 30 minutes since bankers could give limited time. Probing questions were asked wherever required. Some of the main questions asked were: how do you define workplace spirituality? what helps in creating your workplace spirituality? What are the factors that enriches your experience of workplace spirituality? The interviews taken were then transcribed followed by data cleaning and were shared with the co-authors.

Data has been analyzed through thematic analysis (Saldaña, 2009). As part of the process, initial codes were assigned to the interview transcript that the co-authors cross checked and had a discussion to ensure appropriate codes are assigned. This practice increased the validity and the reliability of the coding process. Codes are "tags or labels for assigning units of meaning to the descriptive or inferential information compiled during a study. Codes usually are attached to "chunks" of varying size- words, phrases, sentence or whole paragraphs, connected or unconnected to a specific setting. They can take the form of a straightforward category label or a more complex one (e.g. metaphor)" (Miles \& Huberman, 1994: p.56). The way codes were assigned depends upon the research questions (Saldaña, 2009). Similar codes were then built into higher codes, followed by themes and thematic categories that took it towards a higher level of abstraction. The thematic codes and the thematic categories are shown in Table 2.

Table 2: Building Thematic Categories

\begin{tabular}{|c|c|}
\hline Thematic Codes & Thematic Category \\
\hline Serving humanity & $\begin{array}{c}\text { Finding inner peace and happi- } \\
\text { ness through serving humanity } \\
\text { and religion }\end{array}$ \\
\cline { 1 - 1 } Serving religion and connecting with God & $\begin{array}{c}\text { The concern of earning halal or } \\
\text { haram }\end{array}$ \\
\cline { 1 - 1 } Increased dedication and commitment & $\begin{array}{c}\text { Conflicting fatwas on Islamic } \\
\text { banks and job satisfaction }\end{array}$ \\
\cline { 1 - 1 } Concern for an interest free job & \\
\cline { 1 - 1 } Concern of hereafter (i.e. life after death) & \\
\cline { 1 - 2 } Job retention due to earning halal & \\
\cline { 1 - 2 } Job satisfaction related to understanding of Islamic banking & \\
\cline { 1 - 2 } Conflicting fatwas creating confusions among employees & \\
\cline { 1 - 2 } Lack of understanding of Islamic banking &
\end{tabular}




\section{Findings}

Since workplace spirituality is a highly personal phenomenon, therefore, the findings have been divided into two main sections. The first section elaborates the way employees working in Islamic bank defined workplace spirituality. The second section shows the three thematic categories that emerged from the thematic analysis: finding inner peace and happiness by serving humanity and religion, the concern for earning 'halal' or 'haram, confusions created due to conflicting fatwas (i.e. legal opinion by a recognized authority in Islam on a point in Islamic law) on Islamic banks and the way it influences job satisfaction.

\subsection{Workplace spirituality is a matter of salvation}

Findings show that nearly all the respondents defined and elaborated workplace spirituality in terms of religion. Hence, the religious perspective of spirituality remained dominant. Some respondents related all their worldly deeds with the hereafter, that is, life after death, which is crucial for every Muslim. Selling conventional banking products to the customers were considered to be "haram" and, therefore, they had chosen to work in Islamic banks to seek salvation both in this world and in the hereafter.

"When you ask about workplace spirituality, the mind automatically goes to religion. It's our faith that anything that will happen after death will be directly linked with whatever we have done here. After death, I have to give answer to the Almighty. So, whatever I do here will give me benefit after death; means you do everything thinking about death, that is, spirituality that defines our work here" (mufti/auditor)

For other respondents, workplace spirituality was not confined to one's own deeds and actions rather preaching people about the religious aspects of Islamic banking and convincing them to use halal products instead of choosing the products from the conventional banks. This further enhanced their workplace spirituality. The following quote demonstrates that inner peace and having a sense of purpose is essential to attain workplace spirituality together with understanding the meaning of life and having a connection with others.

"Workplace spirituality is more of an individual practice and has to do with having a sense of peace and purpose. It also relates to the process of developing beliefs around the meaning of life and connection with others." (top management)

Thus, as the following respondent summarizes working in Islamic bank has a noble cause with a hope to gain reward in the hereafter. This sense of belief builds 
an individual's connection with God:

"So, if I am promoting Islamic banking industry, I do get salary here, but at least there is a cause, and it is a noble cause. I will get a reward after death. So, it means spirituality is connecting with God" (frontline staff member).

Another respondent suggested:

"Workplace spirituality is basically to make all the actions and deeds to seek the pleasure of Allah, and to get closer to Him" (mufti/auditor).

The findings assert that employees working in Islamic banks define workplace spirituality in terms of religion, and that religion plays a dominant role in their lives.

\subsection{Finding inner peace and happiness through serving humanity and religion}

Working in Islamic bank and preaching about Islamic products to the customers who would otherwise go for conventional banking is considered to be serving humanity, religion, and an act of worship. Several respondents felt satisfaction over working in Islamic banks that is based on Islamic values and principles. They believed that it was an act of worship as all the transactions and trades were based on religion.

"To work in Islamic bank is also an act of worship because all the transactions and trade are based upon religion" (middle manager)

They felt happier as they believed that they were working for the benefit of the society, which was seen as an act of worship too. On probing further, the respondent said that promoting Islamic banking is fair and just with the customers and, hence, would uplift the society.

"We are happy because we do great work for the benefit of society as well as it's worship for all of us" (top management).

Another respondent elaborated his feeling of joy, satisfaction, and happiness as he felt blessed upon joining Islamic bank. This was related to inner peace, which is an aspect of workplace spirituality that he did not experience while working in a conventional bank.

"After coming to this job, I am enjoying it really. I feel happiness. I feel blessed and my heart is satisfied, and I have found inner peace, which was not there before when I was working in the conventional bank" (frontline staff member). 
Others felt a more intense feeling of being uncomfortable and developing anxiety while working in a conventional bank. One of the respondents thought that Islamic baking is based upon religion; hence, joining an Islamic bank relieved him from all fears and anxiety and made him relaxed.

"As a Muslim, it was an honor for me to join Islamic bank. Before this, I was working in a conventional bank which gave me a lot of anxiety and I felt very uncomfortable. Islamic banking is according to religion. Now, I am very relaxed" (top management).

Hence, shifting from conventional banks to Islamic banks helped the employees to attain inner peace and happiness that is one of the important aspects of workplace spirituality.

\subsection{The concern of earning "halal" or "haram"}

The underlying aspect of working in Islamic banks to achieve workplace spirituality is the matter of either earning halal or haram. This notion is deeply rooted in the religious values of the Muslims. Nevertheless, riba or usury is strictly prohibited in Islam and is considered to be one of the big sins in Islam to an extent that even getting involved in these transactions is haram. Most of the employees who had left conventional banks and had joined Islamic banks were those who were concerned about earning halal to satisfy their workplace spirituality.

"Being a Muslim, one should follow Islamic rules and as per Islamic rules, interest is haram and all the transactions, which are based on riba are prohibited in Islam. That is why I came towards Islamic banking because it is halal" (middle manager).

Others who started their career in a conventional bank were eager to shift to Islamic banks since its halal. Some of them left their better jobs in which they earned more salaries and had more benefits.

"I was in $\mathrm{xxx}$ (conventional) bank, and had a very valuable seat. But I always prayed to God to get me another job that would be halal. I tried so many places, then I saw this advertisement, and I applied. I really wanted it and I got it Alhamdulillah! I also performed Umrah and now I'm very happy in this bank rather than the previous bank" (Branch manager).

Working in Islamic banking meant that their earning is halal and that would help them in the salvation

"Working in Islamic bank is useful both for this world and the hereafter 
because it is halal" (mufti/auditor).

Hence, working in Islamic banks was a matter of their inner satisfaction of their conscience.

"My conscience is satisfied that I am doing a halal job. There is a satisfaction that after doing all the hard work, I am earning halal" (branch manager).

The fact that the bankers were doing a halal job ensured their retention. They clearly stated that they would not leave their jobs in Islamic banks and move to conventional banks even if they offered them with better salaries. The only option to quit was to move to another Islamic bank.

"I will leave this job if any other Islamic bank and not conventional bank offers me a better salary, else I will not leave" (frontline staff member).

Another respondent denied better opportunities from conventional banks and decided to stay in an Islamic bank

"I got many opportunities from other banks, better than this one, but I

did not go there because this is Islamic bank" (middle manager)

This indicates that religious beliefs and values that the bankers were earning halal remained dominant despite of being offered better opportunities and salaries in conventional banks.

\subsection{Conflicting fatwas on Islamic banks and job satisfaction}

The power of the fatwas can be reflected from the fact that most of the employees join Islamic banks due to it. Most of the employees chose to work in Islamic banks over conventional banks to gain spirituality that they defined in terms of religion. A senior manager said:

"When we conduct interviews of MBA degree holders, we ask them that why they want to work in Islamic bank and why not in a conventional bank. They have only one answer that: sir, because it is Islamic banking and some mufti karam say that it is right, so they have level of spirituality due to which they come" (top manager).

Though the employees experienced workplace spirituality in terms of religion; it varied with the level of understanding of employees about the extent to which the Islamic banking complied with the shariah law. Hence, there were situations when doubts were created amongst some employees that shook their confidence in work- 
ing in Islamic banks. One main reason were the conflicting fatwas that demoralized Islamic bankers and created confusions among those who did not know thoroughly about the way Islamic banks function. A mufti who is also an auditor in an Islamic bank gives an example of a fatwa:

"the case becomes more complicated when I have a discussion with friends who are religious Scholars and Mufti. On Eid-ul Adha, there was a "Fatwa" that people who are working in banking sector should sacrifice their animals separately and they can't take part in any collective sacrifice. So, things like that has a great impact on our workplace spirituality and we feel dissatisfied from our jobs" (Auditor/Mufti).

Another main reason that affected workplace spirituality and job satisfaction of the employees was their lack of understanding on whether Islamic banks really function on Islamic principles.

"We have mentality, from what I have seen in banking sector, the thing which we do not understand we immediately start taking it as a wrong thing. So, if we do not understand Islamic banking, we immediately consider it wrong, but this is not true" (top manager).

This is also reflected when even the senior bank managers believed that Islamic bank is not different from the conventional banks.

"I have seen it in so many places, even the managers are sitting there, the branch managers, where we do audit. So, when they sit one to one they ask me that mufti sahib, we have been banking for the last 15 years or 20 years, the ones who are at senior level, the aged ones, that we do not see any difference between conventional and Islamic banks. It's like two sides of the same coin, so we, ourselves are becoming the hurdle since the banking staff itself does not have any know how about it" (mufti/auditor).

Most of the senior bankers who understood Islamic banking suggested that there is a lack of training of new employees to educate them on how Islamic bank works. Failure to do so makes them believe that there is no difference between Islamic and conventional banks that profoundly affected their trust and faith.

“So, he wouldn't have known how Islamic banking works. He will only (learn), from his senior...when management does not give attention to junior staff who deals with customers; they misguide them. So, workplace spirituality goes down due to lack of proper training" (middle manager).

Also, this shows that lack of awareness and proper understanding of the func- 
tioning of Islamic banks is crucial for the frontline staff who are usually ignored since they deal with customers. Inability to answer the queries of the customers regarding Islamic banking can create doubt among the customers and, hence, their customer base can get affected.

"Those who are not getting spiritual satisfaction will have many repercussions. So, if the management does not utilize it properly, because spirituality has an impact on your motivation" (top manager).

Those employees who were ambiguous or lacked an in depth understanding on how an Islamic bank works were willing to look for other better opportunities in conventional banks whereas those who had a deeper knowledge of the functioning of the Islamic banks refused to switch to conventional banks despite of offers of higher salaries. Ultimately, employees who lacked understanding of the functioning of Islamic banks based on shariah would leave when they found better opportunities elsewhere, since they do not see any difference between Islamic and conventional banking.

"When they come they are very happy but when they are confused about Islamic banking and it does not end, then they try to run/leave within 2 months, or that they can get any other job so that they can leave/run from here. We have seen it many/multiples time, there are so many (examples)" (mufti/auditor).

Apart from the employees understanding of Islamic banking, the lack of understanding of the society and the family also creates a challenging situation for the Islamic bankers as depicted from the following quote:

"My personal (issues) matter (parents not happy toward me because of label of bank and societies people also). But I was tried to deal with everyone patiently" (front line staff member).

Thus, the understanding of the functioning of Islamic banking on the basis of shariah is significant to have employee motivation, commitment and retention as it adversely affects their workplace spirituality.

\section{Discussion and Conclusion}

This study shows that workplace spirituality is enacted in Islamic banks due to religion. Islam is the dominant religion in Pakistan and according to Muslims, Allah is supervising all our deeds and the way we act (Khanifar, Jandaghi, \& Shojaie, 2010). Findings show that in order to avoid punishment on the day of judgement, Muslims avoid actions which have been prohibited by God (Ahmadi, 2007). Presence of God 
in the life of Muslims is a prevalent part and plays a very important role in shaping behavior of individuals (Khanifar et al., 2010). In contrast to the secular communities, Islamic communities believe in an invisible "observation system" (ibid, p.568). When true teachings of Islam penetrate the soul of believers, they engage in deeds which are deemed right by Allah and avoid those which are prohibited, as it is believed that their deeds are under observation. It is established in Islam that usury and interest is forbidden; hence, working in Islamic banks enabled participants of study engage in halal work, thus considering themselves fulfilling their spiritual needs.

Though researchers who bifurcate spirituality and religiosity may categorise it as religiosity and not workplace spirituality. However, since Islam is considered as a complete code of life that guides one's actions of everyday life, individuals found meaning in their work due to religious beliefs and practices. Findings show that the belief that they were working for a noble cause and for the sake of Almighty boosted their workplace spirituality. This gave them inner peace and happiness and enabled them to find meaning in work. In literature, this is considered as an intrinsic-origin and existentialist view by Krishnakumar \& Neck (2002) and a metaphysical and humanistic perspective by Twig et al. (2001). However, on the contrary, this study shows that finding meaning at work and gaining inner peace and happiness actually revolves around religion, which is a theoretical contribution. This again creates confusion for other researchers as to whether to distinguish religion from spirituality as shown by Tackney et al. (2017). It is, therefore, argued that the way individuals give meaning to workplace spirituality is highly contextual in nature. In Western societies, it can be seen from a secular perspective whereas in the Eastern societies where religion dominates the work life, it is entirely based upon religiosity. Thus, the distinction between religiosity and religious workplace spirituality no longer remains distinct in this study as contrast to previous research (Kale \& Shirivastav, 2002; Bhunia et al., 2012; Weitz et al., 2012).

\section{Managerial Implications}

This study shows that the intrinsic - origin view and the existentialist view of Krishnakumar and Neck (2002) is embedded in religion, which is substantially different in secular societies where the two views exists beyond religion. This is a crucial finding which has significant practical implications for the top management team and the policy makers. Unlike other organizations, employees derive meaning in their work and satisfy their inner consciousness through religiosity in Islamic banks. Hence, the institutionalization of workplace spirituality in terms of religiosity can result in both instrumental and non-instrumental benefits. Nevertheless, research shows that organizations without workplace spirituality ultimately result in higher absenteeism 
and turnover rates, greater workplace stress, and depression (Thomspon, 2000). The encouragement of workplace spirituality fosters creativity, honesty and trust, personal fulfilment, and increased commitment (Krishnakumar \& Neck, 2002), individual wellbeing and work attitudes (Milliman et al., 2003; Garg, 2017) and greater profitability (Thompson, 2000).

The study shows that workplace spirituality of employees was affected when they were bewildered whether Islamic banks works based on Islamic principles in true spirit. This guides the top management of the Islamic banks and the policy makers to constitute and enhance workplace spirituality at workplace through adequate trainings that Islamic banks are shariah compliant. This would further help to eradicate the confusions created by conflicting fatwas that shake their workplace spirituality. Hence, an in depth understanding of the functions of the Islamic banks is paramount in boosting workplace spirituality that ultimately has several organizational benefits. However, retention of employees in Islamic banks has been found as the main benefit of workplace spirituality in Islamic banks. Secondly, deeper and appropriate understanding of the functioning of Islamic banks will help the employees to convince the potential customers towards Islamic banking. This will improve the customer base of the Islamic banks as several employees are skeptical whether Islamic banks do work on Islamic principles. In conclusion, workplace spirituality can be institutionalized by the top management team of the Islamic banks by encouraging employees to align their spirituality with the organizational goals.

\section{References}

Ashmos, D. P., \& Duchon, D. (2000). Spirituality at work: A conceptualization and measure. Journal of Management Inquiry, 9(2), 134-145.

Ahmadi, M, (2007). Supervising and control. Tehran: Roshd Publication.

Bhunia, A., \& Das, S. A. (2012). Explore the impact of workplace spirituality on motivations for earnings management-an empirical analysis. International Journal of Scientific and Research Publications, 2(2), 153-161.

Burr, V. (2003). Social constructionism (2 ${ }^{\text {nd }}$ ed.). London: Routedge.

Benefiel, M. (2003). Mapping the terrain of spirituality in organizations research. Journal of Organizational Change Management, 16(4), 367-377.

Creswell, J. (2005). Educational research: Planning, conducting, and evaluating quantitative and qualitative research. NJ: Upper Saddle River.

Chapra, M. U. (1986). Towards a just monetary system. Leicester: The Islamic Foundation. 
Daniel, J. L. (2015). Workplace spirituality and stress: Evidence from Mexico and US. Management Research Review, 38(1), 29-43.

Freshman, B. (1999). An exploratory analysis of definitions and applications of spirituality in the workplace. Journal of Organizational Change Management, 12(4), 318-329.

Garcia-Zamor, J. C. (2003). Workplace spirituality and organizational performance. Public Administration Review, 63(3), 355-363.

Garg, N. (2017). Workplace spirituality and employee well-being: An empirical exploration. Journal of Human Values, 23(2), 129-147.

Giacalone, R. A., \& Jurkiewicz, C. L. (2003). Right from wrong: The influence of spirituality on perceptions of unethical business activities. Journal of business Ethics, 46(1), 85-97.

Gotsis, G., \& Kortezi, Z. (2008). Philosophical Foundations of Workplace Spirituality: A Critical Approach. Journal of Business Ethics, 78(4), 575-600.

Hill, P. C., Pargament, K. I., Hood, R. W., McCullough, J., Michael E., Swyers, J. P., Larson, D. B., \& Zinnbauer, B. J. (2000). Conceptualizing religion and spirituality: Points of commonality, points of departure. Journal for the Theory of Social Behaviour, 30(1), 51-77.

Hornby, A. S. (2000). Oxford advanced learner's dictionary. New York: Oxford University Press.

Houghton, J. D., Neck, C. P., \& Krishnakumar, S. (2016). The what, why, and how of spirituality in the workplace revisited: A 14-year update and extension. Journal of Management, Spirituality $\mathcal{E}$ Religion, 13(3), 177-205.

Kale, S. H., \& Shrivastava, S. (2003). The enneagram system for enhancing workplace spirituality. Journal of Management Development, 22(4), 308-328.

Khanifar, H., Jandaghi, G., \& Shojaie, S. (2010). Organizational consideration between spirituality and professional commitment. European Journal of Social Sciences, 12(4), 558-571.

King, S. M. (2007). Religion, spirituality, and the workplace: Challenges for public administration. Public Administration Review, 67(1), 103-114.

Kinjerski, V. M., \& Skrypnek, B. J. (2004). Defining spirit at work: Finding common ground. Journal of Organizational Change Management, 17(1), 26-42.

Koenig H.G., McCullough M.E., \& Larson D.B. (2001). Handbook of Religion and Health. New York: Oxford University Press.

Clements, W. M., \& Koenig, H. G. (2014). Aging and God: Spiritual pathways to mental health in midlife and later years. Routledge.

Krishnakumar, S., \& Neck, C. P. (2002). The "what", "why" and "how" of spirituality in the workplace. Journal of Managerial Psychology, 17(3), 153-164. 
MacLaren, J. (2004). A kaleidoscope of understandings: Spiritual nursing in a multi-faith society. Journal of Advanced Nursing, 45(5), 457-462.

Miles, M. B., Huberman, A. M., Huberman, M. A., \& Huberman, M. (1994). Qualitative data analysis: An expanded sourcebook. Thosand Oaks: Sage.

Milliman, J., Czaplewski, A. J., \& Ferguson, J. (2003). Workplace spirituality and employee work attitudes: An exploratory empirical assessment. Journal of Organizational Change Management, 16(4), 426-447.

Mitroff, I. I., \& Denton, E. A. (1999). A study of spirituality in the workplace. MIT Sloan Management Review, 40(4), 83-92.

Mukhtar, A., \& Mohsin Butt, M. (2012). Intention to choose Halal products: The role of religiosity. Journal of Islamic Marketing, 3(2), 108-120.

Neck, C. P., \& Milliman, J. F. (1994). Thought self-leadership: Finding spiritual fulfilment in organizational life. Journal of Managerial Psychology, 9(6), 9-16.

Gani, O., A. M., Hashim, J., \& Ismail, Y. (2013). Establishing linkages between religiosity and spirituality on employee performance. Employee Relations, 35(4), 360-376. doi:doi:10.1108/ER-04-2012-0030.

Paloutzian, R.F. (1997). Spiritual well-being: a psychological perspective. Aging E⿱ Spirituality, IX, 1-3.

Patton, M. Q. (1990). Qualitative evaluation and research methods. London: Sage Publication.

Poole, E. (2009). Organisational spirituality - a literature review. Journal of Business Ethics, 84(4), 577-588.

Rassool, G. H. (2000). The crescent and Islam: Healing, nursing and the spiritual dimension. Some considerations towards an understanding of the Islamic perspectives on caring. Journal of Advanced Nursing, 32(6), 1476-1484.

Rego, A., \& Pina e Cunha, M. (2008). Workplace spirituality and organizational commitment: an empirical study. Journal of Organizational Change Management, 21(1), 53-75.

Saldaña, J. (2009) The coding manual for qualitative researchers. London: Sage Publications, Inc.

Spilka, B. (1993). Spirituality: Problems and directions in operationalizing a fuzzy concept. Paper presented at the meeting of the American Psychological Association, Toronto, Ontario.

Thompson, W.D. (2000). Can you train people to be spiritual? Training and Development, 54(12), 18-19

Twigg, N., Wyld, D., \& Brown, G. (2001). Quest for fire: A redefinition and reconceptualization of spirituality at work. Available at: http:// spiritatwork.com/uversity/Twigg\%20Wild\%20Brown.htm (Accessed April 27, 2001).

Tackney, C. T., Chappell, S., Harris, D., Pavlovich, K., Egel, E., Major, R., . . Stoner, J. (2017). Management, Spirituality, and Religion (MSR) ways and means: A paper to encourage quality research. Journal of Management, Spirituality $\mathcal{E}$ Religion, 14(3), 245-254. 
Van der Walt, F., \& De Klerk, J. J. (2014). Workplace spirituality and job satisfaction. International Review of Psychiatry, 26(3), 379-389.

Weitz, E., Vardi, Y. \& Setter, O., 2012. Spirituality and organizational misbehavior. Journal of Management, Spirituality E Religion, 9(3), 255-281.

Wilson, J. A. J., \& Liu, J. (2010). Shaping the Halal into a brand? Journal of Islamic Marketing, 1(2), 107-123.

Witmer, J.M. (1989), "Reaching toward wholeness: an integrated approach to well being over the life span”, in T. J. Sweeney, T.J. (Eds.), Alderian Counseling: A Practical Approach for a New Decade (pp. 30-45) Muncie: Accelerate Press.

Yousef, D. A. (2000). Organizational commitment as a mediator of the relationship between Islamic work ethic and attitudes toward organizational change. Human Relations, 53(4), 513-537.

Zinnbauer, B. J., Pargament, K. I., \& Scott, A. B. (1999). The emerging meanings of religiousness and spirituality: Problems and prospects. Journal of Personality, 67(6), 889-919. 